Published in AJSE, Vol:18, Issue: 03

Received on $10^{\text {th }}$ September 2019

Revised on $11^{\text {th }}$ December 2019

\title{
Impacts of Electric Vehicle Charging On Distribution Grid
}

\author{
Md. Nazmul Haque, Ahmed Mortuza Saleque
}

\begin{abstract}
Electric Vehicle is one of the most emerging technology in modern era. Different type of latest technologies are used in today's electric vehicles as well as the battery technology is also developed. Besides many advantages of electric vehicles there are some bad impacts of electric vehicles charging on electric grid. Analysis of Electric Vehicle charging impacts on distribution grid are highly importance for the development of electric vehicles. In this paper a very simplified model is used by MATLAB/Simulink to analyze the Electric vehicle charging impacts on distribution grid. In this model Vehicle to grid (V2G) technology is also used to analyze the grid power. The active power of distribution grid was measured while EVs were charging for both V2G on and off cases and the differences between this two conditions were measured from the simulation and the results were compared. In this paper the impacts of EV charging on other grid connected loads are also analyzed.
\end{abstract}

Keywords-Power generating station, Electric vehicles charging station, Vehicles to Grid (V2G), MATLAB/Simulink model, Analysis grid power, Supplying power to the grid by V2G.

\section{INTRODUCTION}

Environment pollution, rising price of fossil fuels, low efficiency of gasoline powered vehicles and lot of advantages of Electric vehicles over gasoline powered vehicles such as, Clean technology, Almost zero emission of greenhouse gases, Higher efficiency, Cheaper Electricity cost compare to fossil fuels etc. led the Electric Vehicle as the prime alternative source of transportation sector [1]-[3]. The users of electric vehicles are increasing day by day due to these several advantages. In future the users of electric vehicles will increase a lot as many countries have set zero emission goal in their transportation sector. Although electric vehicles have many positive benefits over gasoline powered vehicles, the rapid acceptance of electric vehicles may have significant bad impacts on distribution grid such as decreasing power quality, increasing harmonics into the system, transformer aging effect, higher load current

\section{Md. Nazmul Haque}

American International University-Bangladesh (AIUB)

Dhaka, Bangladesh

Email: nazmulhaque.aiub@gmail.com

\section{Ahmed Mortuza Saleque}

American International University-Bangladesh (AIUB)

Dhaaka, Bangladesh

E-mail: saleque@aiub.edu
(Which can damage others equipment, power shortage etc. [1][4]. High amount of power will be consumed by electric vehicles in near future. A study showed that $6 \%$ peak demand of total demand is consumed by electrical vehicles in 2013 in Los Angeles. Another study showed that by 2035, total peak demand will be $20 \mathrm{GW}$ in UK [4][5].

Previous researchers tried to find out the impacts of EV charging on power grid, They just discussed about the impacts of EV charging on grid (such as reducing power level, voltage drop, harmonics, system loss, transformer aging, power quality etc.[6]-[11]) or discussed about the probable solution model to reduce those impacts[12][13]. But in this paper the proven solution model is discussed with experimental data's along with the impacts of EV charging. This model can be used to solve the power shortage problem during peak hour demand and for this purpose no extra power station is required. So it is also cost effective and economical solution for peak hour power shortage problem.

The objectives of this study is to build a simple EV charging model to analyze the impacts of EV charging on distribution grid and analyze the importance of vehicle to grid (V2G) technology to tackle the power shortage problem during peak hour period or any emergency situation when total peak demand increases rapidly. In this paper a EV charging scheme is proposed where EV charging stations are separated from residential areas and due to this, the impacts of EV charging on residential loads is almost negligible and one most important thing is that this model can be used to deliver power to the grid by Vehicle to Grid (V2G).

\section{Methodology OF EV DESIGN IN SIMULINK}

This work is based on MATLAB/Simulink model. An equivalent electric vehicle model with an equivalent battery model was built in Simulink [14]. The basic EV drive module is consists of battery controller, battery, EV interface, motor, motor controller etc.

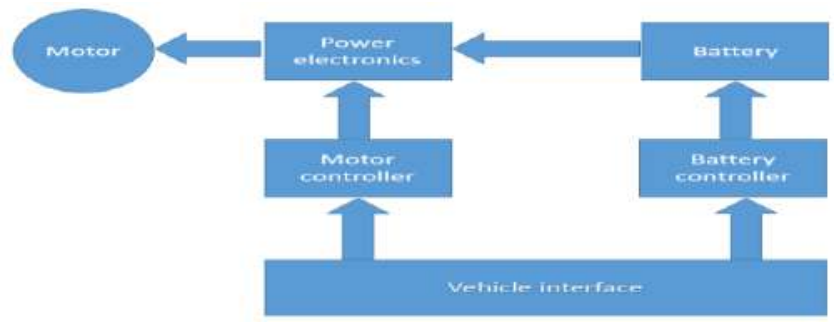

Fig 1: EV drive module [14]. 
Different power rated batteries are used in electric vehicles by famous automobile companies like, Tesla, Volvo, Toyota, Nissan, BMW etc.

\begin{tabular}{|c|c|c|}
\hline Electric Car Name & Type of battery & Rated capacity \\
\hline Tesla model S & Lithium-ion & $85 \mathrm{kWh}$ \\
\hline Nissan Leaf & Laminated Li-ion & $24 \mathrm{KWh}$ \\
\hline Rimac C Two & Lithium-ion & $120 \mathrm{kWh}$ \\
\hline Toyota RAV4 & Nickel-metal hydride & $41.8 \mathrm{kWh}$ \\
\hline
\end{tabular}

In this paper the battery rated power was considered as $40 \mathrm{~kW}$. Rated capacity was considered as $85 \mathrm{kWh}$ and Lithium-ion battery was considered for the simulation.

In this simulation model the EV model with different components were designed in Simulink and the values for different components were set according to almost exact values of those components.

The purpose of simulation is to simulate and analyze the performance of the vehicle with changing the different unit's parameters. In this section different units and blocks would be discussed with related parameters [15][16]. Then details of the blocks will be discussed. The overall EV model was modelled and simulated in Matlab/Simulink. The basic building blocks for electric vehicles are discussed below.

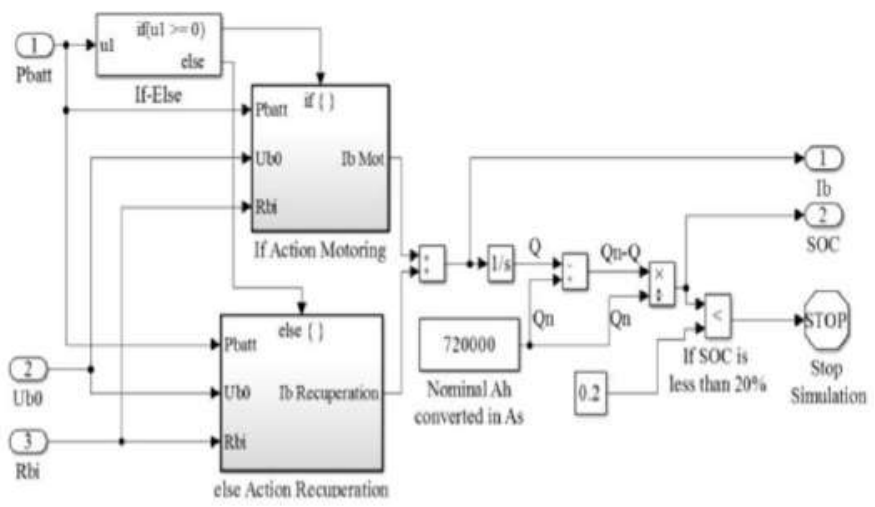

Fig 2: Battery model [15]

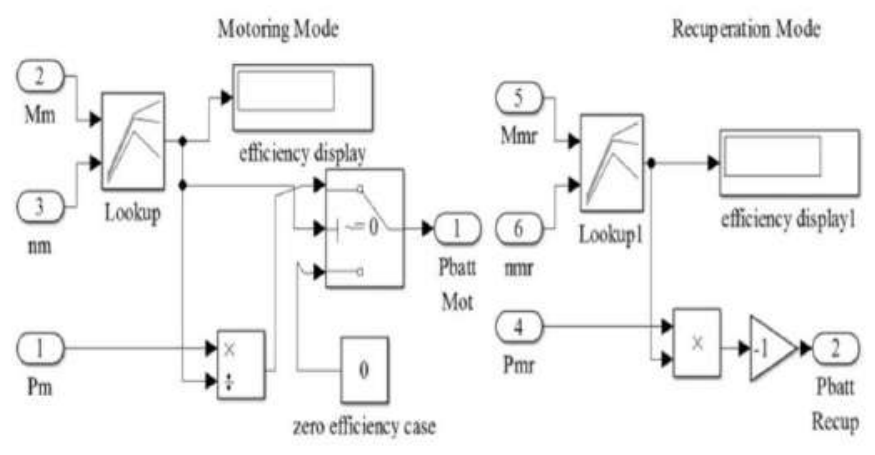

Fig 3: Motor/inverter model [15]

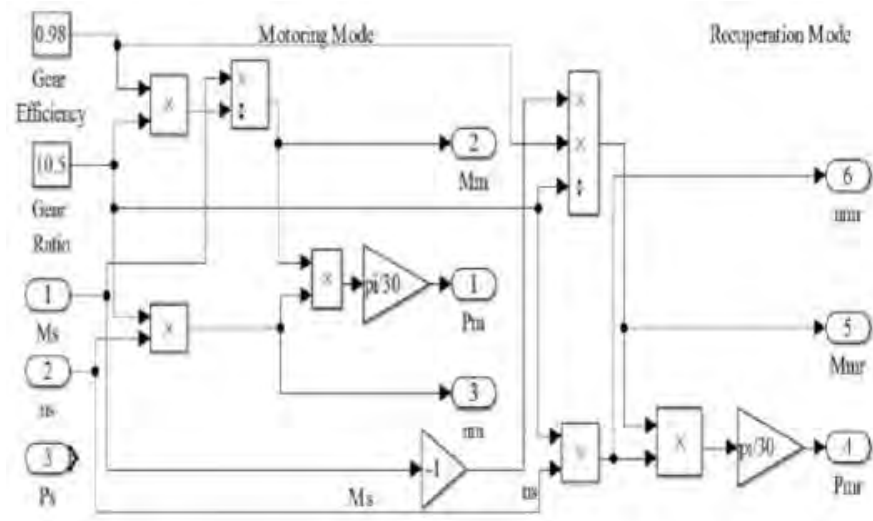

Fig 4: Gearbox model [15]

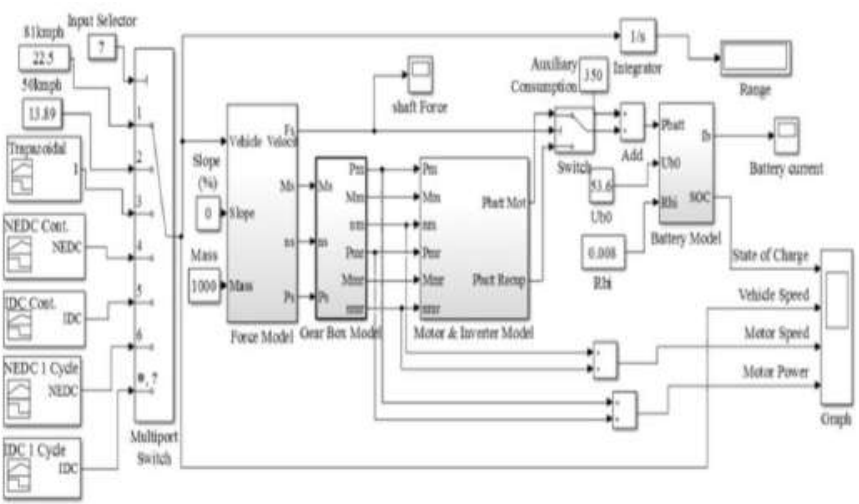

Fig 5: Overall EV model [15]

In simulation model the equivalent model of an electric vehicle is done in Simulink by providing mechanical and electrical inputs which are approximately equal to a physical electric vehicle's value.

\section{SIMULATION}

The Simulink model consists of four major parts. Such as:

1. Generating station

2. Step down transformer

3. EV charging station

4. Connected loads (Residential and industrial)

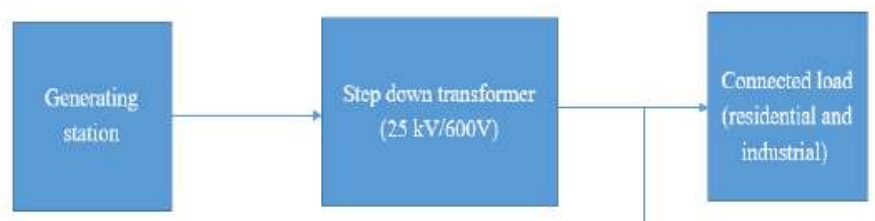


The generating power can be varied to analyze the EV charging impacts with amount of total power. Initially the simulation was done for total $15 \mathrm{MW}$ generating power which was produced by synchronous machines.

In this Simulink model $600 \mathrm{~V} \mathrm{AC}$ was used to charge the electric vehicles. The generating station primarily produced 25 $\mathrm{kV}$ then this voltage level was reduced to $600 \mathrm{~V}$ by step-down transformer.

One of the most significant characteristics of this model is that the total EV charging station was separated from residential loads. The EV stations were directly connected to the main distribution grid. Maximum 100 vehicles were connected to the charging station which consumed total $4 \mathrm{MW}$ power from the grid. The total number of vehicles were varied to see the charging impacts on grid. In this simulation model minimum 2 vehicles and maximum 100 vehicles were used to analyze the charging impacts.

Two type of others load were connected to the main grid, one is residential load and other one was considered as industrial load. Total $10 \mathrm{MW}$ residential load and $0.16 \mathrm{MW}$ of industrial were considered. Power factor of the residential load was considered as 0.95 .
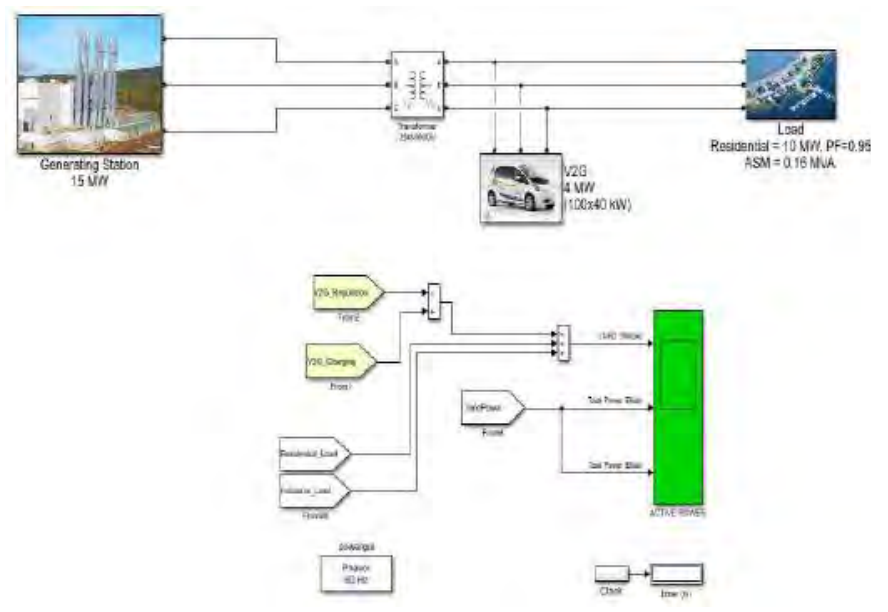

Figure 7: Overall MATLAB/Simulink model

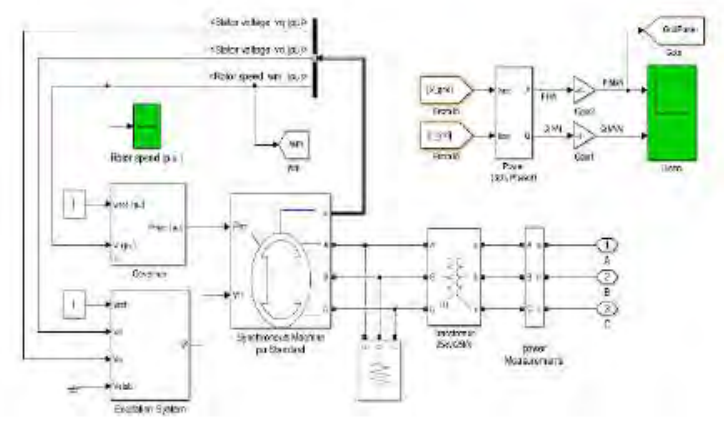

Figure 8: Generation Station model

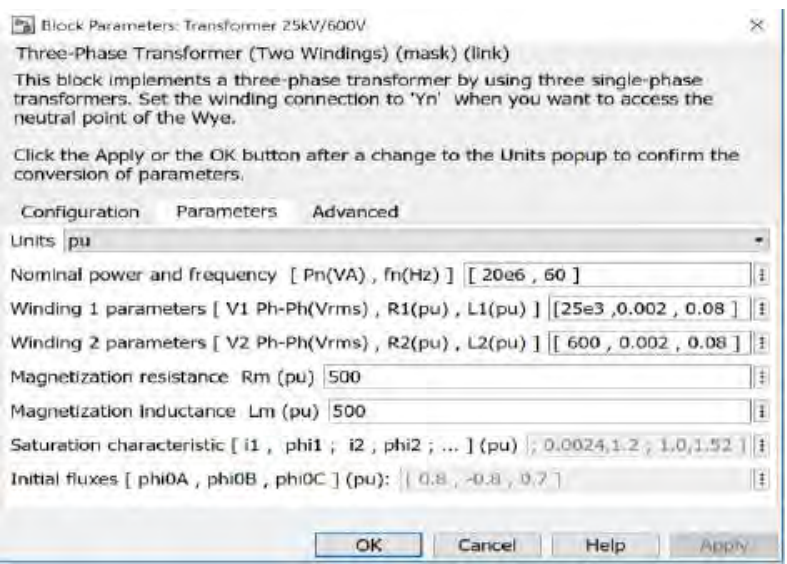

Figure 9: Transformer parameters

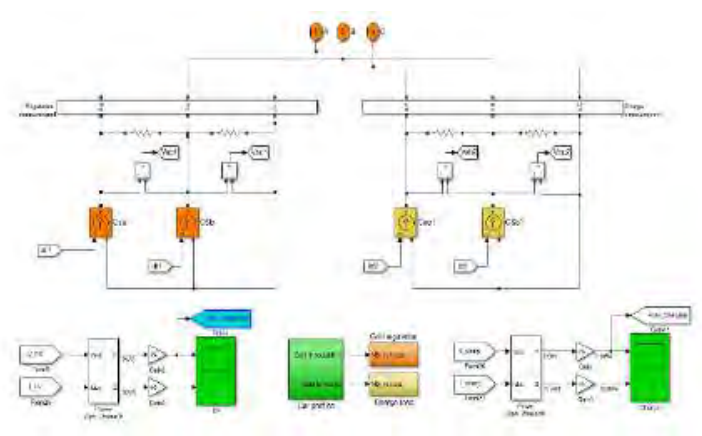

Figure 10: EV charging model

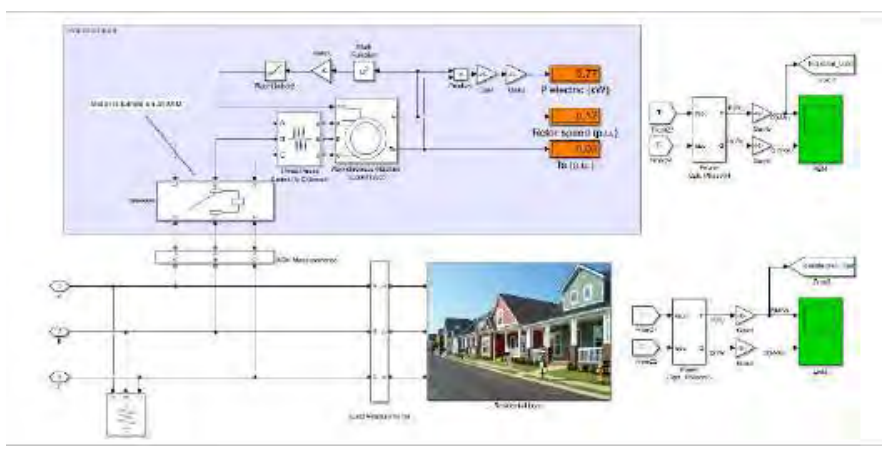

Figure 11: Connected load (residential \& industrial) model

In this simulation model, vehicle to grid (V2G) technology is used to supply power to the distribution grid from the vehicles after fully charged. The system efficiency is considered as $90 \%$ and total five (5) charging profiles are used in this model to analyze the charging effect by varying the vehicle number. 


\section{RESULTS ANALYSIS}

The results were analyzed with different conditions. Load active power, active and reactive power of residential load and industrial load were analyzed with different combinations of EV charging.

\section{A. Analysis of grid active power}

\section{Conditions:}

Total generating power $=15 \mathrm{MW}$

Total EV=2

Profile $1=0 \mathrm{EV}$, Profile $2=0 \mathrm{EV}$, Profile $3=1 \mathrm{EV}$,

Profile 4=1 EV, Profile 5=0 EV

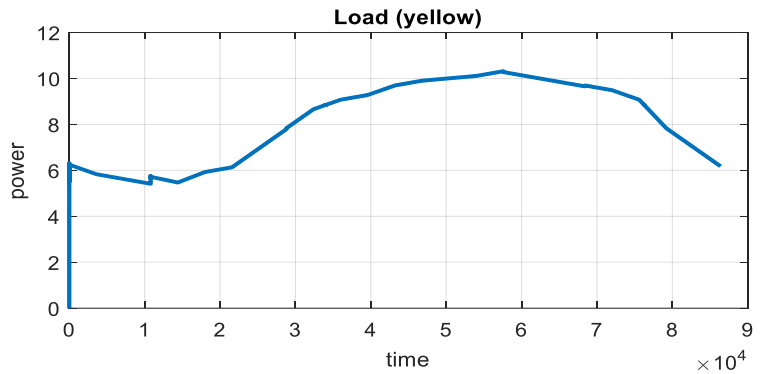

Figure 12: Grid active power (V2G on)

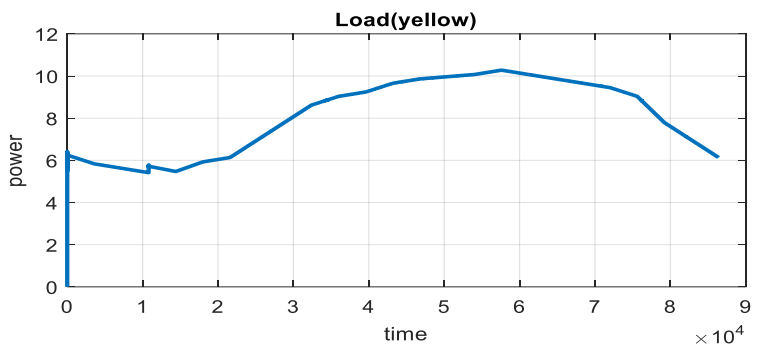

Figure 13: Grid active power (V2G off)

\section{Conditions:}

Total generating power $=15 \mathrm{MW}$

Total EV=50

Profile $1=10 \mathrm{EV}$, Profile $2=10 \mathrm{EV}$, Profile $3=10 \mathrm{EV}$,

Profile 4=10 EV, Profile 5=10 EV

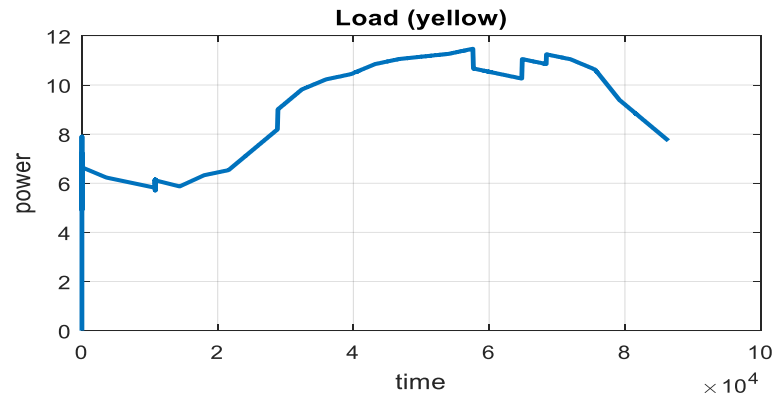

Figure 14: Grid active power (V2G on)

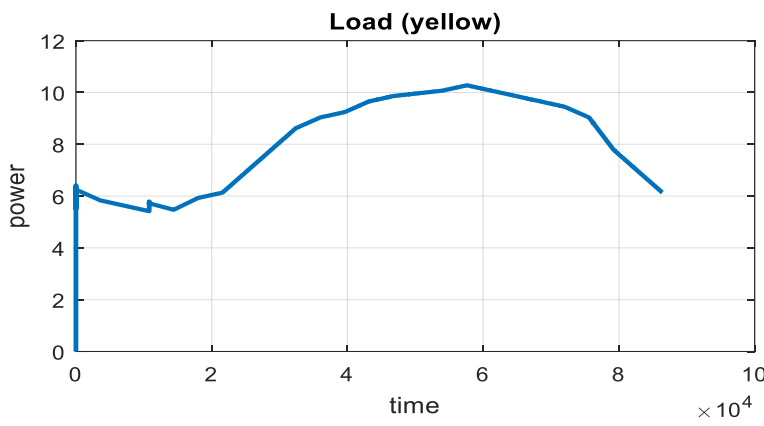

Figure 15: Grid active power (V2G off)

\section{Conditions:}

Total generating power $=15 \mathrm{MW}$

Total EV=100

Profile 1=35 EV, Profile 2=25 EV, Profile 3=10 EV, Profile 4=20 EV, Profile 5=10 EV

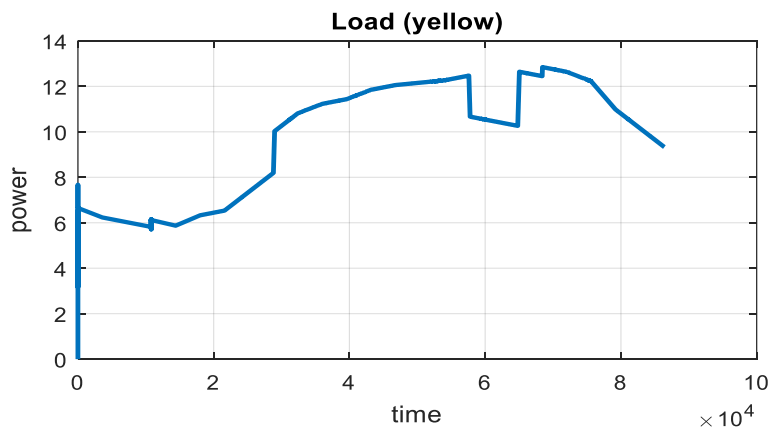

Figure 16: Grid active power (V2G on)

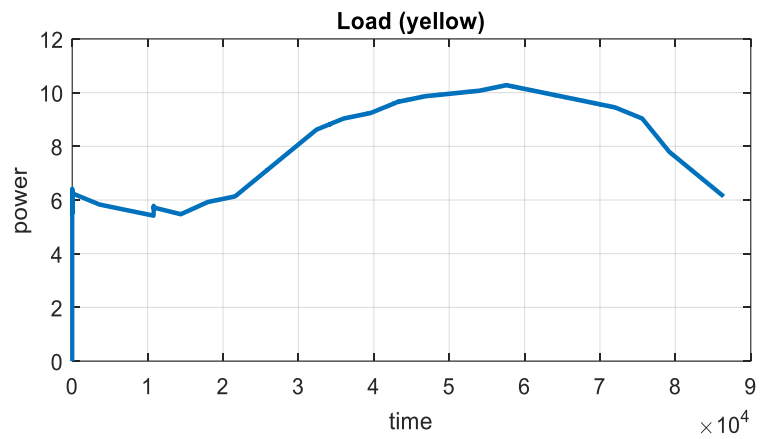

Figure 17: Grid active power (V2G off)

\section{Conditions:}

Total generating power $=20 \mathrm{MW}$

Total EV=2

Profile $1=0 \mathrm{EV}$, Profile $2=0 \mathrm{EV}$, Profile $3=1 \mathrm{EV}$,

Profile $4=1 \mathrm{EV}$, Profile 5 $=0 \mathrm{EV}$

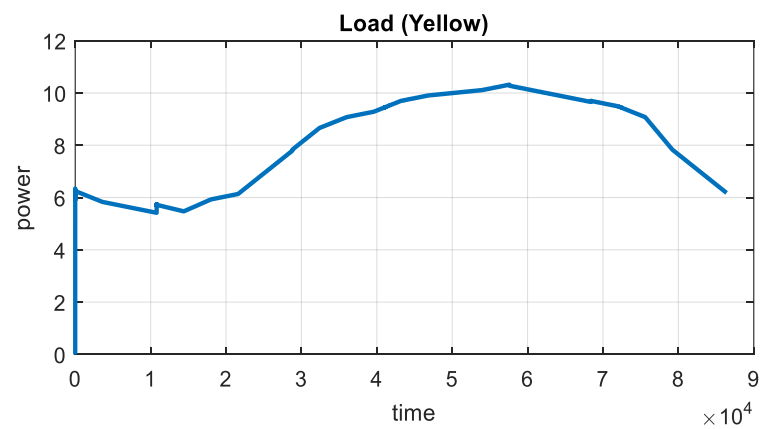

Figure 18: Grid active power (V2G on) 


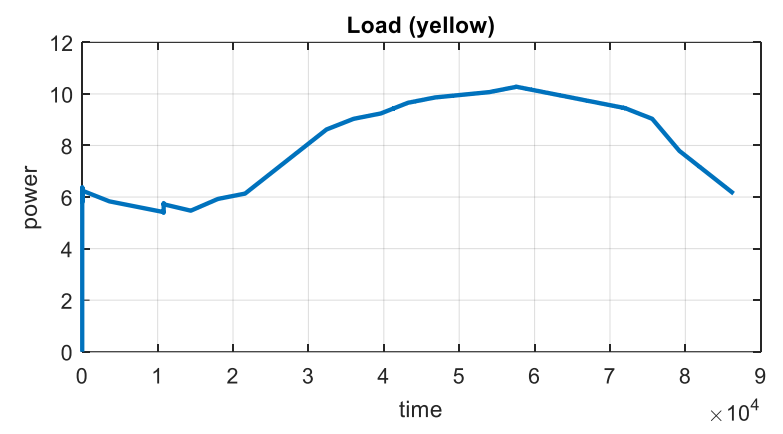

Figure 19: Grid active power (V2G off)

\section{Conditions:}

Total generating power $=20 \mathrm{MW}$

Total EV=50

Profile $1=10 \mathrm{EV}$, Profile $2=10 \mathrm{EV}$, Profile $3=10 \mathrm{EV}$, Profile 4=10 EV, Profile 5=10 EV

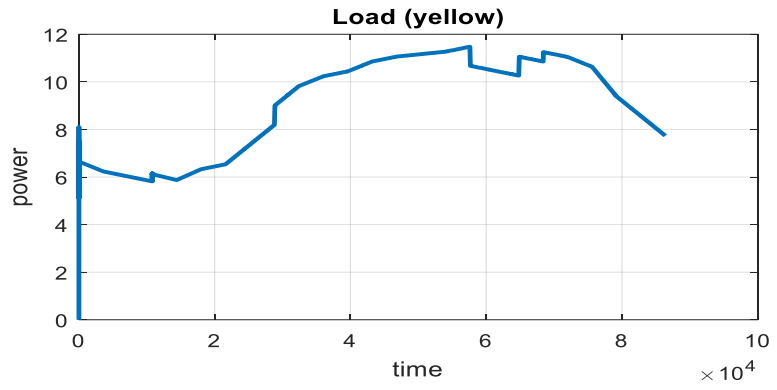

Figure 20: Grid active power (V2G on)

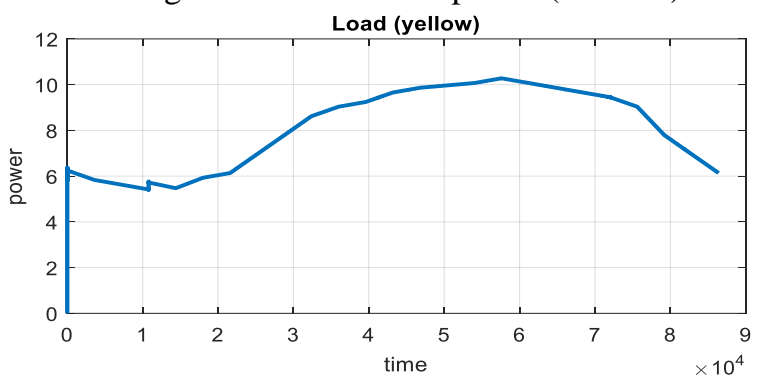

Figure 21: Grid active power (V2G off)

\section{Conditions:}

Total generating power $=20 \mathrm{MW}$

Total EV=100

Profile 1=35 EV, Profile 2=25 EV, Profile 3=10 EV, Profile 4=20 EV, Profile 5=10 EV

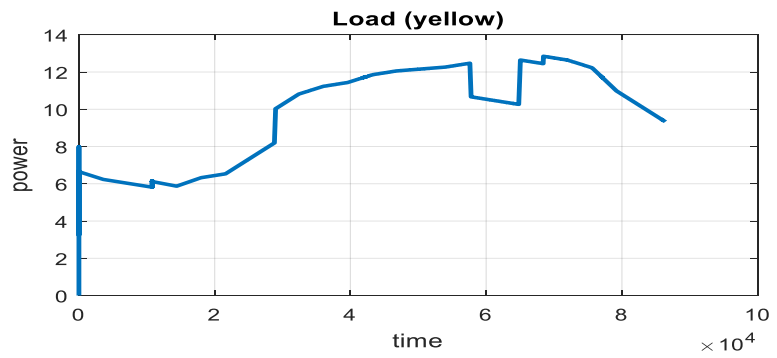

Figure 22: Grid active power (V2G on)

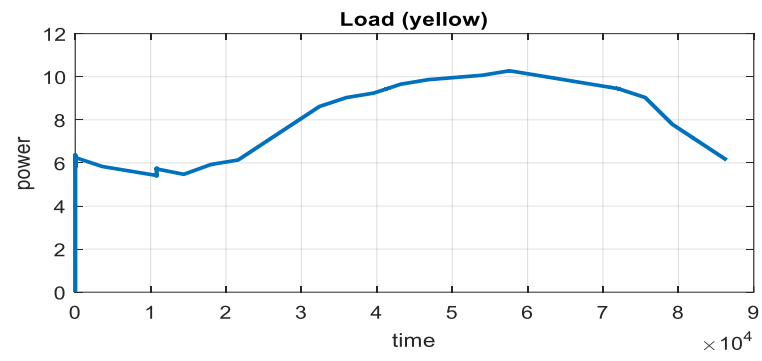

Figure 23: Grid active power (V2G off)

From the above figures it is clear that during V2G on the grid power is higher than V2G off. That means when V2G is on, after full charged the EV supplies power to the main grid as a result the grid power increases. When very less amount of vehicles (here 2 vehicles) are in charging station, the difference between power when $\mathrm{V} 2 \mathrm{G}$ on and off is not noticeable. It means that less numbers of vehicle doesn't increase the grid power although vehicle to grid remaining on. But when higher number of vehicles are in charging and vehicle to grid is on, significant amount of power can be supplied to the grid by the EVs. By calculating the power differences between $\mathrm{V} 2 \mathrm{G}$ on and off for different combinations. The tables below show the power contribution by $\mathrm{V} 2 \mathrm{G}$ on compare to $\mathrm{V} 2 \mathrm{G}$ off.

\section{Comparison Grid power for V2G on and off}

\begin{tabular}{|c|c|c|c|c|}
\hline \multicolumn{5}{|c|}{ For 15 MW Generating Power } \\
\hline $\begin{array}{l}\text { Total } \\
\text { EV }\end{array}$ & $\begin{array}{l}\text { Power in MW } \\
\text { (V2G off) }\end{array}$ & $\begin{array}{l}\text { Power in MW } \\
\text { (V2G on) }\end{array}$ & $\begin{array}{l}\text { Power } \\
\text { increase }\end{array}$ & $\begin{array}{l}\text { Increase } \\
\text { in \% }\end{array}$ \\
\hline 2 & 10.25 & 10.3 & 0.05 & 0.4878 \\
\hline 50 & 10.3 & 11.4 & 1.1 & 10.68 \\
\hline 100 & 10.3 & 12.9 & 2.6 & 25.24 \\
\hline
\end{tabular}

The above table is for total $15 \mathrm{MW}$ generating power. The table shows that for 2 vehicles V2G can contributes only $0.4878 \%$ power to the grid which is almost negligible. But when 100 vehicles are in charging V2G contributes $25.24 \%$ power to the distribution grid which is huge amount of power.

Now let's calculate this for $20 \mathrm{MW}$ generating power.

Comparison Grid power for V2G on and off

\begin{tabular}{|c|c|c|c|c|}
\hline \multicolumn{5}{|c|}{ For 20 MW Generating Power } \\
\hline $\begin{array}{l}\text { Total } \\
\text { EV }\end{array}$ & $\begin{array}{l}\text { Power in MW } \\
\text { (V2G off) }\end{array}$ & $\begin{array}{l}\text { Power in MW } \\
\text { (V2G on) }\end{array}$ & $\begin{array}{l}\text { Power } \\
\text { increase }\end{array}$ & $\begin{array}{l}\text { Increase } \\
\text { in \% }\end{array}$ \\
\hline 2 & 10.3 & 10.35 & 0.05 & 0.49 \\
\hline 50 & 10.3 & 11.5 & 1.2 & 11.65 \\
\hline 100 & 10.3 & 13 & 2.7 & 26.21 \\
\hline
\end{tabular}

The above table is for total $20 \mathrm{MW}$ generating power. The table shows that for 2 vehicles V2G can contributes only $0.49 \%$. But for 100 vehicles it contributes $26.21 \%$. This scenario indicates that for higher generating power contribution of $\mathrm{V} 2 \mathrm{G}$ is also higher. 


\section{B. Analysis of active \& reactive power of residential load}

In this section active and reactive power of residential load would be analyzed. By varying total no. of vehicles, Total residential load, power factor etc. We will try to find the impacts.

\section{Conditions:}

Total generating power $=15 \mathrm{MW}$

Residential load $=10 \mathrm{MW}$

Total EV=50,

Profile 1=10 EV, Profile 2=10 EV, Profile 3=10 EV,

Profile 4=10 EV, Profile 5=10 EV

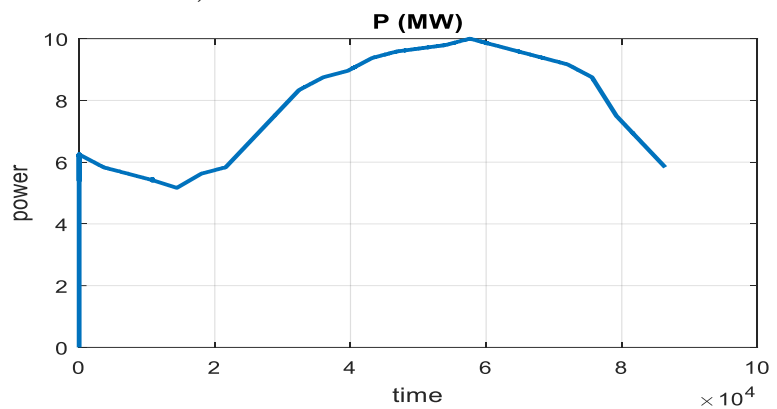

Figure 24: Load active power (V2G on)

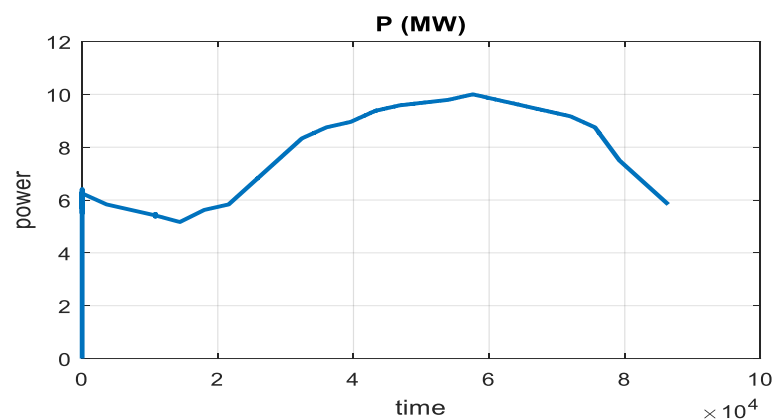

Figure 25: Load active power (V2G off)

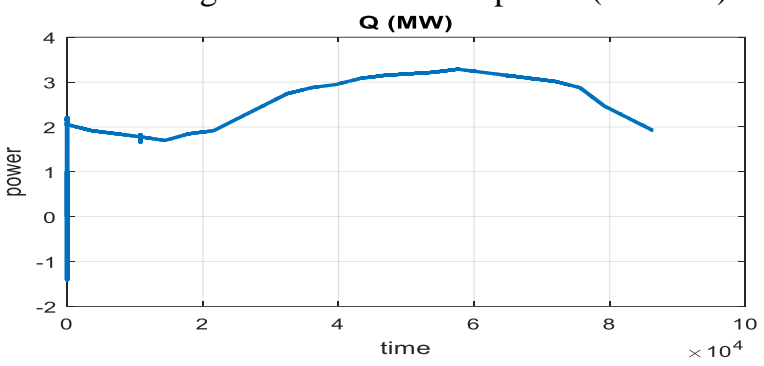

Figure 26: Load reactive power (V2G on)

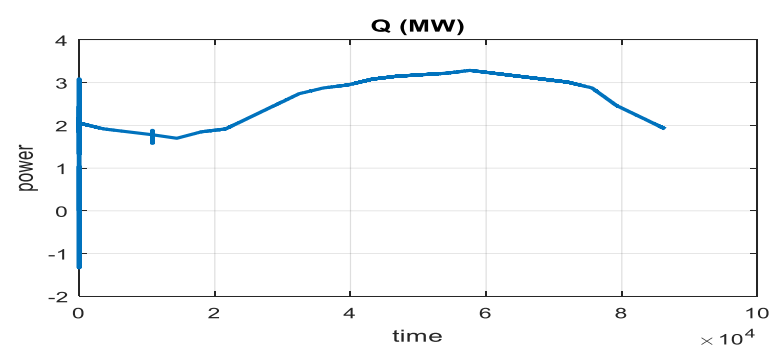

Figure 27: Load reactive power (V2G off)

\section{Conditions:}

Total generating power $=15 \mathrm{MW}$

Residential load $=10 \mathrm{MW}$

Total EV=100,

Profile $1=35$ EV, Profile $2=25$ EV, Profile $3=10$ EV,

Profile 4=20 EV, Profile 5=10 EV

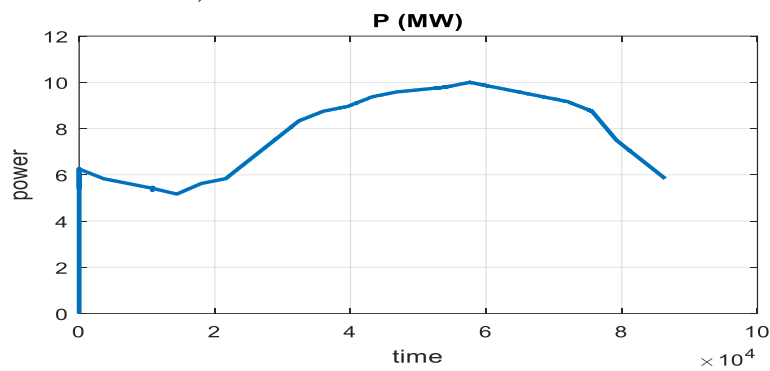

Figure 28: Load active power (V2G on)

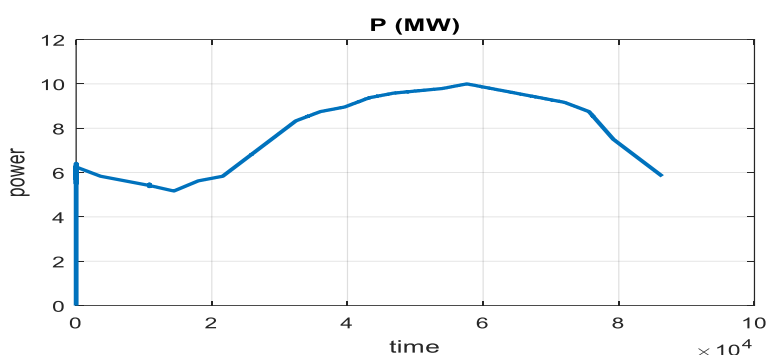

Figure 29: Load active power (V2G off)

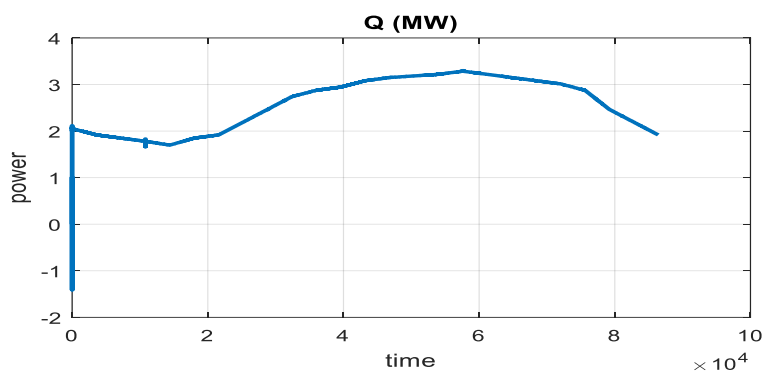

Figure 30: Load reactive power (V2G on)

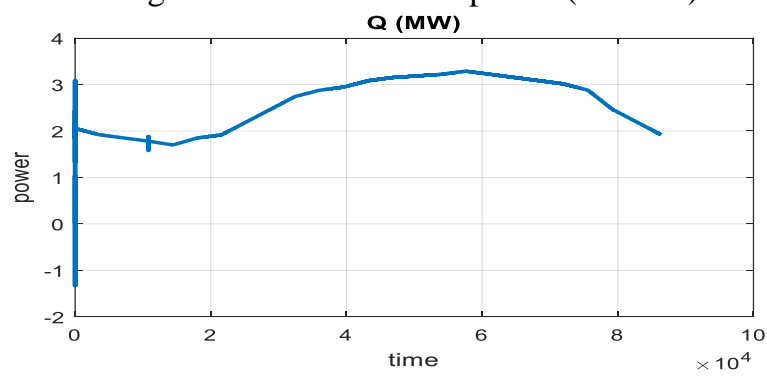

Figure 31: Load reactive power (V2G off) 


\section{Conditions:}

Total generating power $=20 \mathrm{MW}$

Residential load $=10 \mathrm{MW}$

Total EV=100,

Profile $1=35 \mathrm{EV}$, Profile $2=25 \mathrm{EV}$, Profile $3=10 \mathrm{EV}$,

Profile 4=20 EV, Profile 5 $=10 \mathrm{E}$

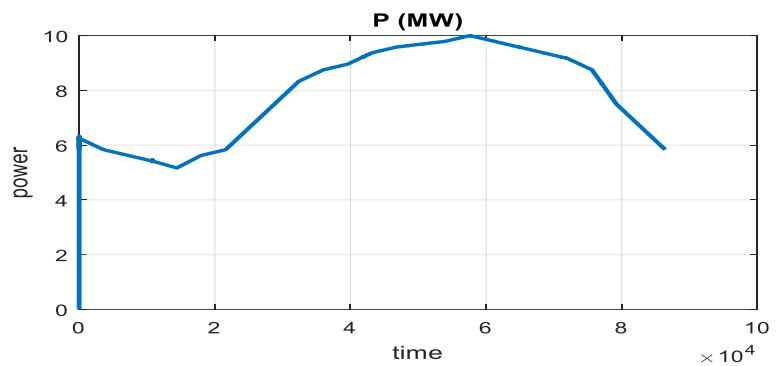

Figure 32: Load active power (V2G on)

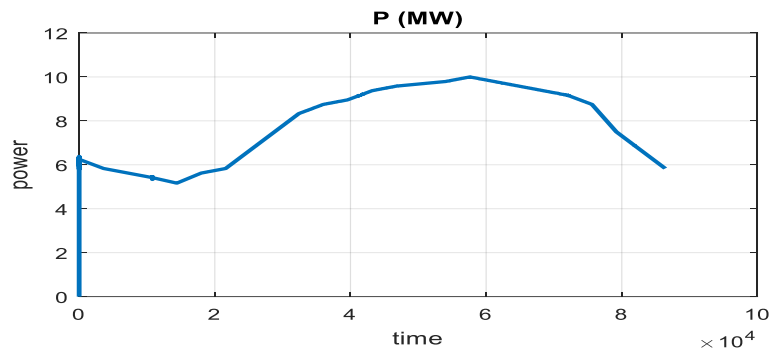

Figure 33: Load active power (V2G off)

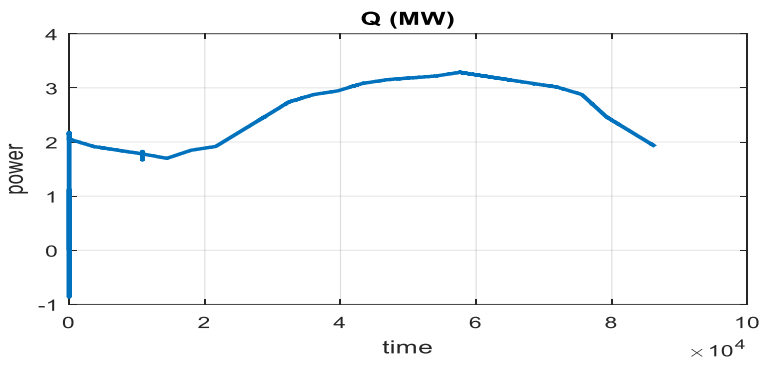

Figure 34: Load reactive power (V2G on)

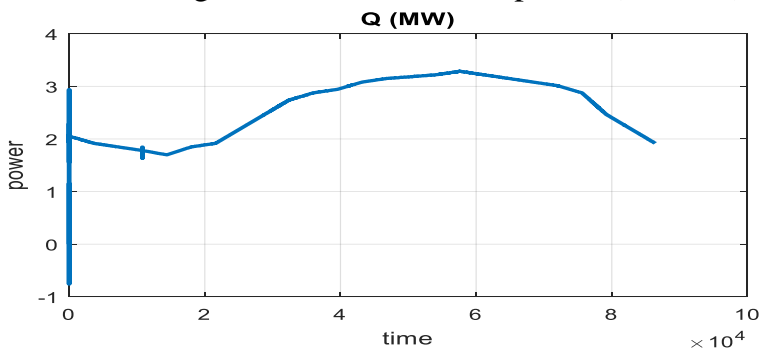

Figure 35: Load reactive power (V2G off)

From the above wave shapes it is observed that the active and reactive power of residential load doesn't affected with vehicles charging in grid. Here V2G on or off is not effective for load power. So it can be said that EV charging has almost no effect on residential load as EV charging stations are separated from residential zone.

\section{Analysis of Active \& reactive power of Asynchronous machines (Industrial Load)}

In this section both active and reactive power of connected industrial load will be analyzed by varying the total number of electric vehicles and total generating power. Here total residential load is considered as $0.16 \mathrm{MW}$.

\section{Conditions:}

Total generating power $=15 \mathrm{MW}$

Total EV=100,

Profile 1 $=10$ EV, Profile 2=10 EV, Profile 3=10 EV, Profile 4 $=10 \mathrm{EV}$, Profile 5=10 EV

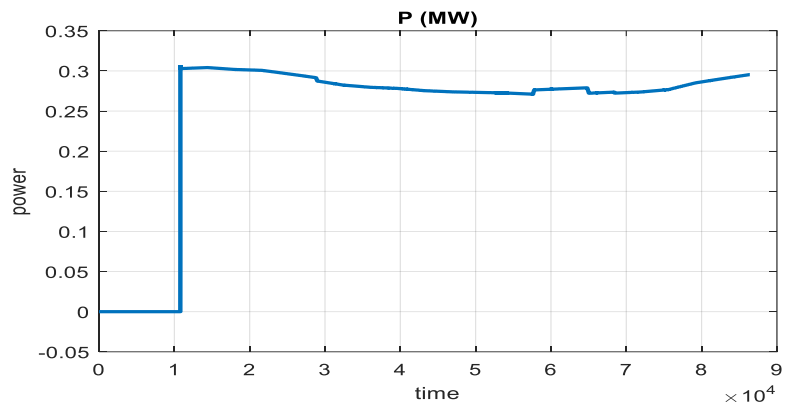

Figure 36: ASM active power (V2G on)

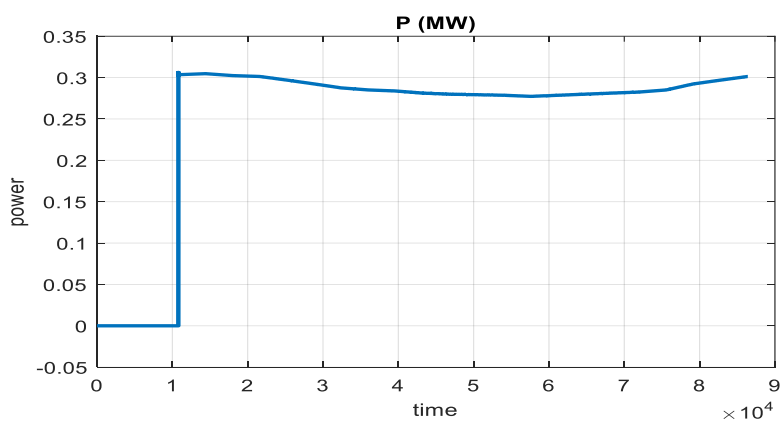

Figure 37: ASM active power (V2G off)

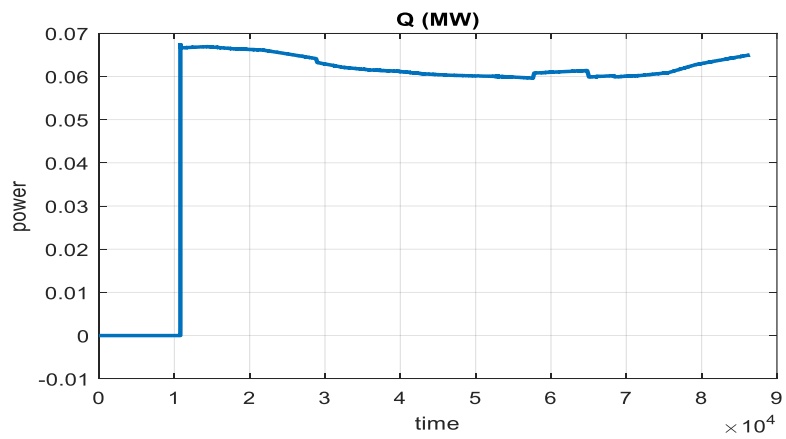

Figure 38: ASM reactive power (V2G on) 


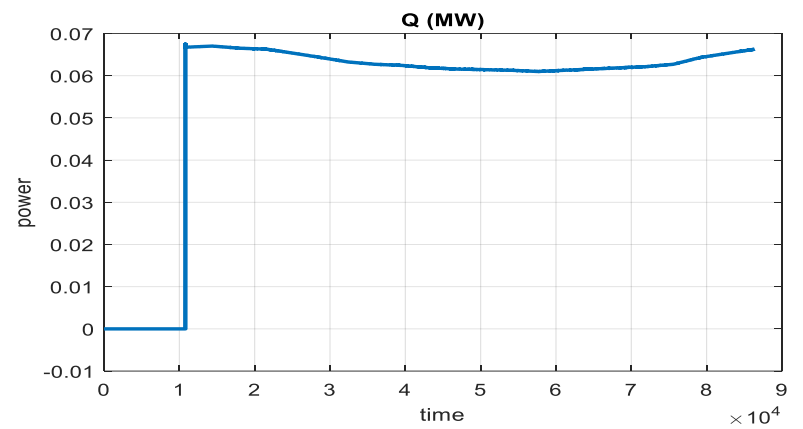

Figure 39: ASM reactive power (V2G off)

From the above figures, it is clearly seen that the ultimate peak value of the active \& reactive power of ASM (asynchronous machines) is almost same. But when V2G is in on condition, EVs trying to supply some power to the grid (between 5.30 to 6.30 O'clock). The amount of supplied power by the vehicles to the grid is almost negligible. So we can say that impacts of EV charging on industrial load (ASM) is almost zero if EV charging station is directly connected to the grid and totally separated from others connected load.

\section{CONCLUSION}

The experiment was successfully done. In this work, the EV charging station is totally separated from others load and directly connected to distribution load. As a result it was observed that only main distribution grid is affected but other connected loads are not affected at all. During the charging period the active power of main grid decreases but after fully charged EV starts to supply power to the main grid while V2G system is in on mode. But due to V2G off, EV can't supply any power to the main grid. So V2G system is very effective. It was measured that for the charging case of 100 vehicles, due to V2G on EV can supply more than $25 \%$ (for $15 \mathrm{MW}$ grid it is $25.24 \%$ and for $20 \mathrm{MW}$ grid it increases to $26.21 \%$ ) power to the main grid.

The previous studies have shown different EV charging impacts on grid and have proposed different type of solution to reduce those impacts. But in this paper a very simple EV charging scheme is designed and a built in Vehicle to Grid (V2G) technology is used as a solution is proposed that is by default technology in many modern electric vehicles now a days. So for the solution of EV charging impacts on grid, there will be no extra charges. The novelty of this proposed work is very simple in design, residential areas are almost out of the EV charging impacts zone and most importantly after full charge, huge amount of power can be supplied to the grid when $\mathrm{V} 2 \mathrm{G}$ remains on. This power can be used during peak hour to fulfill the peak demand.

\section{REFERENCES}

[1]. Z. Darabi, M. Ferdowsi, "Aggregated impact of plugin hybrid electric vehicles on electricity demand profile", 2017 IEEE Green Energy and Smart Systems
Conference (IGESSC)IEEE Transactions onSustainable Energy, vol.2, no. 4, 2011, pp. 501-508.

[2]. L. Pieltain Fernández, T.G.S. Román, R. Cossent, C.M. Domingo, P. Frías, "Assessment of the Impact of plug-in electric vehicles ondistribution networks", IEEE Transactions on Power Systems, vol. 26,no. 1, 2011, pp. 206-213.

[3]. Zeming Jiang; Shalalfeh, L.; Beshir, M.J., "Impact of electric vehicle infrastructure on the city of Chatsworth distribution system," Electric Vehicle Conference (IEVC), 2014 IEEE International Electric Vehicle Conference, 17-19 Dec. 2014, vol., no., pp.1,5.

[4]. Marcelo Di Paolo, " Analysis of Harmonic Impact of Electric Vehicle Charging on the Electric Power Grid ", 2017 IEEE Green Energy and Smart Systems Conference (IGESSC), 6-7 Nov. 2017, pp. 1-5.

[5]. B. Gough, P. Rowley, C. Walsh " What impact will the journey patterns of electric vehicles have on their capability to provide ancillary services? ", 5th IET Hybrid and Electric Vehicles Conference (HEVC 2014), London, UK, 5-6 Nov. 2014, pp. 1-5.

[6]. A. Dubey, S. Santoso, and M. P. Cloud, "Understanding the effects of electric vehicle charging on the distribution voltages", Proc. IEEE Power Energy Soc. General Meeting, Jul. 2013, pp. 15.

[7]. A. Dubey, S. Santoso, and M. P. Cloud, "A practical approach to evaluate voltage quality effects of electric vehicle charging," in Proc. Int. Conf. Connected Vehicles Expo., Dec. 2013, pp. 188-194.

[8]. J. C. Gomez and M. M. Morcos, "Impact of EV battery chargers on the power quality of distribution systems,' IEEE Trans. Power Del., Jul. 2003, vol. 18, no. 3, pp. 975-981.

[9]. Bass, Robert, and Nicole Zimmerman. "Impacts of Electric Vehicle Charging on Electric Power Distribution Systems". OTREC-SS-731. Portland, OR: Transportation Research and Education Center (TREC), 2013.

[10]. E. Sortomme, M. M. Hindi, S. D. J. MacPherson, and S. S. Venkata, "Coordinated charging of plug-in hybrid electric vehicles to minimize distribution system losses,' IEEE Trans. Smart Grid, Mar. 2011, vol. 2, no. 1, pp. 198-205.

[11]. J. R. Pillai and B. Bak-Jensen, "Impacts of electric vehicle loads on power distribution systems," in Proc. IEEE Vehicle Power Propuls. Conf. (VPPC), Sep. 2010, pp. 1-6.

[12]. Saeid Gholami Farkoush, Si-Na Park, Kyu-Ho Kim, Sang-Bong Rhee "Improvement of network voltage distortion when Electric Vehicles are connected to smart grid with SRFC and NVC ". International Journal of Applied Engineering Research ISSN 09734562, March 2016, vol. 11, no 2. 
[13]. Shan Chuan Wang, Jian Xun Jin, Ying Li Wang, "SMES Effect in a Smart Grid with Electric Vehicles". IEEE International Conference on Applied Superconductivity and Electromagnetic Devices, Shanghai, China, November 20-23, 2015, pp. 530531.

[14]. T.A.T. Mohd, M.K. Hassan, WMK. A. Aziz, "MATHEMATICAL MODELING AND SIMULATION OF AN ELECTRIC VEHICLE". International Conference on Automotive Innovation and Green Energy Vehicle (AiGEV 2014), Kuantan, Pahang, Malaysia, August 26-27, 2014.

[15]. Aalok Bhatt, "Planning and Application of Electric Vehicle with MATLAB/Simulink". IEEE International Symposium on Power Electronics for Distributed Generation Systems (PEDG), Trivandrum, India, 14-17 Dec. 2016, pp. 1-6.

[16]. Bambang Sri Kaloko, Soebagio, Mauridhi Hery Purnomo "Design and Development of Small Electric Vehicle using MATLAB/Simulink". International Journal of Computer Applications (0975 - 8887), June 2011, Volume 24- No.6.

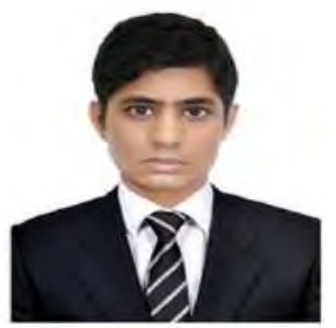

Md. Nazmul Haque was born on 17 July, 1995 in Pabna, Bangladesh. He received the B.Sc. in EEE degree from American International University-Bangladesh (AIUB), in 2018, the M.Sc. in EEE degree from the same University in 2019.

He is currently working as an Assistant Engineer at United General Electric Company Ltd. His research focuses on the areas of renewable power, power automations, power systems etc.

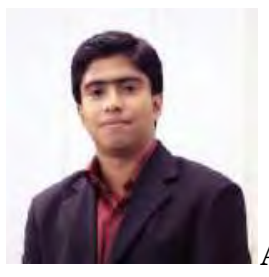

received Bachelor of Science in Electical Electronic Engineering and Master of Engineering in Telecommunications from American International University-Bangladesh in 2010 and 2012 respectively. From 2013 to 2015, he was awarded Erasmus Mundus scholarship for Master's program. He received joint Master degree in Sustainable

Transportation and Electrical Power Systems (EMMC-STEPS) from University of Wisconsin Madison, , University of Nottingham, University of Oviedo, and University of Rome. Currently, he is working as an Assistant Professor, Faculty of Engineering, American International University-Bangladesh 